\title{
Value chain development for mango (Mangifera indica) around Outamba Kilimi National Park in Sierra Leone: constraints and opportunities for smallholders
}

\author{
Ademonla Djalalou Dine Arinloye ${ }^{1}$, Ann Degrande ${ }^{2}$, Vodjo Nicodème Fassinou Hotegni ${ }^{3^{*}}$, Ebenezar Asaah², \\ Rebecca Bockarie ${ }^{1}$, Joachim Binam Nyemeck ${ }^{1}$, Jules Bayala ${ }^{1}$ and Antoine Kalinganire ${ }^{1}$
}

\begin{abstract}
Background: Mango is an important tree fruit in Sierra Leone since it participates to food and nutritional security mainly in rural areas. However, the economic potential of this tree fruit is still untapped to a large extent. This situation is due to high loss and poor handling at post-harvest stage preventing farmers from meeting the quality standard for different markets. The aims of this paper were to analyse the constrains and opportunities for mango value chain development, as well as community-based copping strategies developed by chain actors to valorise the existing opportunities for better market development and forest conservation.

Methods: Data were collected in four sites around the Outamba Kilimi National Park, Sierra Leone, through focus group discussions with men and women groups of 25-35 mango value chain actors in each site.

Results: Results indicated that mango value chain is composed of nursery suppliers, mango producers, harvesters and assemblers, processors and traders. Main constraints encountered by both men and women are lack of: (1) polythene bags and improved mango seedlings, mineral fertilisers, herbicides, pesticide, (2) training on appropriate mango production practices, (3) appropriate harvesting tools, (4) appropriate processing knowledge and equipment, as well as high transportation cost. Hand weeding, use of available organic fertiliser, seeking of advices from colleagues farmers, equipment from other processors who own local processing equipment were some of the coping strategies developed by various actors along mango value chains. Soil fertility, favourable climatic conditions, technical and financial support from direct or indirect actors through training on good agronomic practices, processing and marketing techniques, availability of hired labour to perform farming and processing operations, existence of local processing plant to serve as outlet for fresh mango were identified as main factors to be exploited to improve mango value chains around Outamba Kilimi National Park in Sierra Leone.
\end{abstract}

Conclusions: Our results provided insight into the various factors limiting the performance of mango value chains around Outamba Kilimi National Park in Sierra Leone. This baseline study will help in designing and implementing appropriate strategies to promote mango value chains in the areas around the Outamba Kilimi National Park.

Keywords: Fruit tree, Mango, Value chain, Sierra Leone

\footnotetext{
*Correspondence: nicodemef@gmail.com; nicodeme.fassinou@uac.bj

${ }^{3}$ Laboratory of Genetics, Biotechnology and Seed Sciences (Former

Horticulture and Genetics Unit), Faculty of Agronomic Sciences (FSA),

University of Abomey-Calavi, 01 BP 526, Cotonou, Benin

Full list of author information is available at the end of the article
} 


\section{Background}

During the last decades, many studies pointed out that reserves or forest resources conservation will not be sufficient to cope with climate change effects $[1,2]$. In this respect, many studies and reports are now raising local communities' awareness about the importance of tree planting in/around their cultivated land [3-5]. Among the trees, attention was given to economic trees mainly the fruit trees due to their capacity to provide rural communities with edible fruits with market value. This is the case of mangoes tree (Mangifera indica L.), one of the major fruits produced and consumed in the world mainly in the tropics and subtropics $[6,7]$, and used as supplement to sustain food and nutritional security. The fruit is an important source of nutrients and energy $[6,7]$ because it is rich in amino acids, carbohydrates, fatty acids, minerals, organic acids, proteins and vitamins, mainly vitamins $\mathrm{A}$ and C [8]. Unfortunately, West African countries such as Cape Verde, Niger, Sierra Leone, Togo and Benin are facing problems in taking advantage from this important fruit tree due to the high post-harvest loss ranging between 40 and $50 \%$ of the produced mango [9]. The situation is more pronounced in Sierra Leone where the post-harvest loss in mango was found to be the highest (30\%) with about $5 \%$ of the production meeting the quality standard for export to international markets [10]. Therefore, actions need to be taken to encourage Sierra Leoneans farmers to grow more mango trees so that the country fully benefit from this important fruit crop. A first step towards these actions is the identification and investigation of constraints within prevailing fruit tree value chains as suggested by Unruh [11]. Not only is the identification of the constraints important, but the identification of copping alternatives developed by rural people as well as opportunities and links between actors involved in the fruit tree exploitation is also relevant to improve the performance of the whole fruit tree chains [12]. Hence, this paper aimed at (i) mapping the mango value chains in Sierra Leone with emphasis on therelationship between value chains actors (ii) determining the roles and responsibilities of each value chain actors, and (iii) identifying the constraints and the opportunities of the mango sector in order to set priorities and highlight conditions enabling its dissemination. This will help to increase the willingness of farmers to grow mango tree facilitating its role as biocarbon sequestration; in addition, more income will be generated from the mango tree exploitation. The approach used and discussed in the present study can be adapted and used in the other West African countries, namely Benin, Cape Verde, Niger and Togo.
Background on mango value chains in Sierra Leone

Mango tree was first reported in West Africa in 1824 [13] but could be introduced long before 1824. Since its introduction in West Africa, mango tree spreads over the coastal regions. No data are available in the literature about the period of introduction of mango in Sierra Leone, but we may assume that it was introduced at nearly the same time than in the other West African costal countries. Most of Sierra Leonean mango plantations are wild, justifying the oldness of its introduction and first grown in the country. Mango is being considered as an important tree for job creation and poverty alleviation in Sierra Leone. Since 2011, more than 2000 farmers steadily supply mango fruits to processing factory enabling them to earn substantial income and so far about 5000 jobs have been created in the sector [14]. The interest in mango sector is translated over the last decade (2003-2013) into an increase in the harvested area and yield, resulting in the increase in the production. The annual average production, harvested area and yield were, respectively, about 16,839 t, 5635 ha and 3 t/ ha (Fig. 1). These average values include also mangosteens. The yield is still low as compared to average yield in Africa, which averages $7.8 \mathrm{t} / \mathrm{ha}$ [15]. This is due to the cultivated varieties and the agronomic practices applied by famers [10].

The major mango growing areas in Sierra Leone are located in the Northern Province including Kabala, Port Loko, Kambia, Makeni, Magburaka and Moyamba regions. The average annual rainfall ranges from 2097 to $3095 \mathrm{~mm}$; such relatively high rainfall may favour fungal and bacterial attack in late maturing varieties [16]. In each region, two overlapping harvesting seasons were distinguished with a slight difference across regions. In general, the first harvesting season starts in April and ends in August; the second season spreads from August

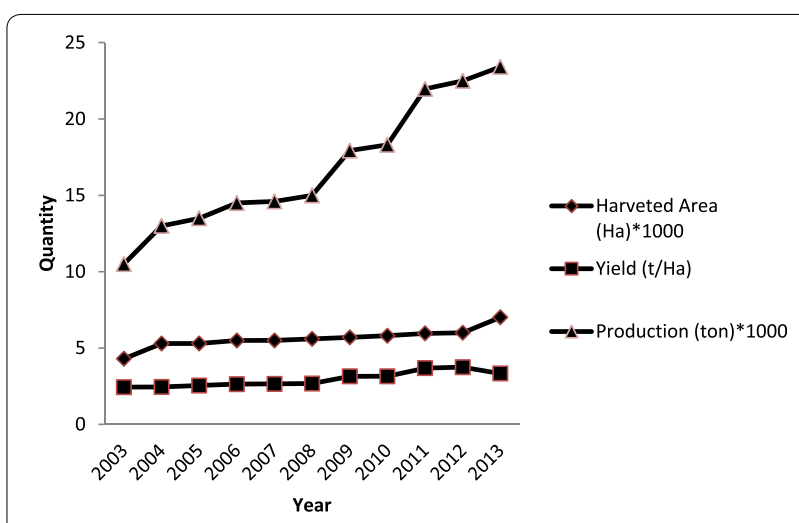

Fig. 1 Trend of mango production, harvested area under mango and mango yield from 2003 to 2013 Source: FAO Statistics Division 2015 
to September [10]. Conversely to the other major mango growing regions in Sierra Leone, in Kabala region, the yield of mango trees is high due to the high soil fertility [10]. This may be a potential area to promote the establishment of new mango orchards in order to benefit from its comparative advantage over the other regions.

\section{Methods}

\section{Study area}

The present study was conducted in the framework of the BIODEV (Building Biocarbon and Rural Development in West Africa) project. The aim of BIODEV project is to generate critical information that can fill the global knowledge gaps on how to better link climate change mitigation and adaptation thrusts and how to make these actions work effectively to enhance the livelihoods of rural communities with special emphasis on identifying and supporting high market potential tree species. Four sites were selected around the Outamba Kilimi National Park (OKNP): Samaya, Fintonia, Sanya and Kabba Ferry (Fig. 2). The sites selection was made in the framework of BIODEV taking into account human, agroecological, landscape characteristics; more specifically, in Sierra
Leone, the sites selection was guided by the existence of forest reserve, and pressure on their conservation considering the population density as well as access to market for non-timber forest products (NTFP). On this respect, Sanya community similarly to Samaya is hosting the Kilimi forest reserve, a forest moderately degraded, with relatively high population density as well as good access to market (Sanya and Thambie periodic markets host on Saturday and Thursday), respectively. Fintonia is selected based on the fact that it has relatively dense forest cover, but poor access to market and moderately populated. Kabba Ferry on the other hand has a highly degraded forest and relatively good access to market because very close to Kamakwie city centre with easy access to Sanya and Thambie periodic markets host on Saturday and Thursday, respectively. Kabba Ferry on the other hand is highly degraded and community in that site has a relatively good access to market (close to Kamakwie city centre).

The OKNP was selected based on its agroecological conditions characterised by a mosaic of grass land, closed wood land, gallery forest farms and home gardens. The climate is tropical humid with two distinct seasons,

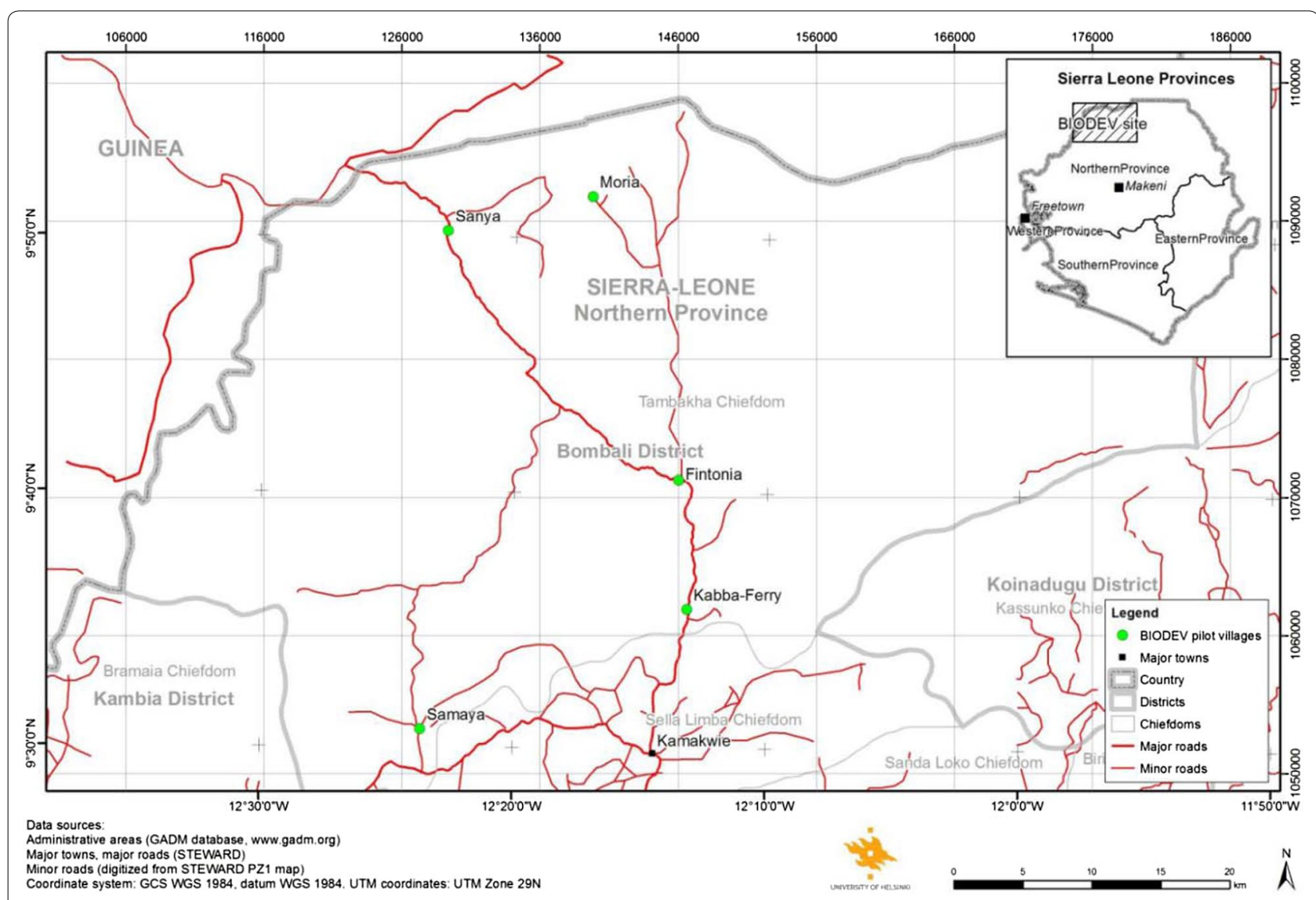

Fig. 2 Location of the sites of the mango value chains study in the Outamba Kilimi National Park (OKNP) area in Sierra Leone, West Africa 
namely the wet season from May to October and the dry season from November to April, each lasting about six months.

\section{Value chain selection}

Focus group discussions were held with four groups of 15 participants each. These categories include adult men, adult women, young men (active male member aged $<25$ years) and young women (active female member aged $<25$ years). Each group lists the species that they considered important and all the products provided by each species based on the abundance and usefulness of the species. Each group discussed and reached a general consensus on five priority tree functions. Scores were assigned to each species for each function by each gender ranging from 0 to 3 where $0=$ not useful and $3=$ very useful. The importance of each species is estimated by calculating the sum of the five tree function scores. The species importance values were then used to select priority species. The four groups met together to present their priority species, discuss the priorities and reach a consensus about the priority species in each of the four communities. The top 10 priority species with high potentials in Bombali district which included Samaya, Fintonia, Kabba Ferry and Sanya Communities are presented in Additional file 1: Table 1. Mango was ranked first tree species presenting several potentials including: human food, animal food, human medicine, income source, shade for human and animal, soil conservation and energy source.

\section{Sampling of respondents}

In each site, a focus group discussion (FGD) was held with about 25 mango value chains actors including nursery producers, producers, harvesters and assemblers, processors and traders (wholesalers and retailers). Criteria to select the mango value chain's actors were their experience in performing mango-related activities and their knowledge in the mango sector mainly with regard to constraints and opportunities.

For a representative mango value chain mapping, there is need to have all value chain actors directly or indirectly involved at each community level. The number of FGD participants including local and improved nursery farmers, local and improved mango producers, harvesters and assemblers, processors, and traders wholesalers and retailers, transporters, consumers, chains enablers (NGOs) and local authority representative is presented in Table 1.

\section{Data collection tools}

Data were collected in the selected sites in July 2014 with the use of a guide containing open questions for focus group interviews. The themes discussed were: (1) direct and indirect actors in the mango chains and their respective roles; (2) relationship between actors in the mango value chain; (3) constraints and coping strategies as well as opportunities associated with mango trees and mango fruits, processing and trading. During the value chain mapping exercise, the relations between actors were depicted using the following materials: brown paper, van cards and voice recorder. With the authorisation of the FGD participants, the voice recorder was used to make sure that key information from the discussion is not lost. The recorded information is later on re-listened to insure concordance between the notes, the transcripts and the reported data. Following the value chain mapping exercise, each value chain actor's group was requested to list and rank the major constraints face in their chain segment, the coping strategies developed (if any) to temporally or definitively overcome these constraints. They were also requested to list and rank the existing opportunities for a successful development of the mango value chain. Constraints and opportunities were ranked from 1 (major) to 4 (minor).

Considering the education and literacy levels of value chains actors in the different sites, for them to be very explicit in the proportion of men and women, ranking, or products flow became unobvious. The stone distribution approach as used by Sheil et al. [17] helped the actors to easily and more accurately provide proportion that are more close to the actual figures.

\section{Data analysis}

Raw data were recorded in Microsoft Excel, and descriptive statistics were calculated and used to describe the chains. SPSS version 19 was used to compute the descriptive statistics parameters. Using information from photographs, van cards and papers, the value chain map was realised and later presented to the community during a feedback meeting for validation.

\section{Results \\ Mango value chains in Sierra Leone}

Figure 3 depicts the mango value chains in the study sites. Two types of actors were distinguished in the mango value chain: direct and indirect actors. Direct actors are those directly involved in mango production and commercialisation and for whom mango plays a significant role in their income generating strategies. These included the nursery producers, fresh mango producers, harvesters and assemblers, processors and the traders.

\section{Nursery supply}

Most mango producers directly sow seeds or collected seedlings under local mango trees and transplant them during the rainy season. Few nurseries operate in the 
Table 1 Category of participants in the focus group discussion per study area

\begin{tabular}{|c|c|c|c|}
\hline Study area & Number of focus group discussions (FGD) & Number of participants & Category of participants (women) \\
\hline \multirow[t]{9}{*}{ Samaya } & 1 & 3 & Nursery producers (0) \\
\hline & & 7 & Producers (2) \\
\hline & & 5 & Harvesters and assemblers (4) \\
\hline & & 7 & Traders (6) \\
\hline & & 2 & Consumers (1) \\
\hline & & 2 & NGO (1) \\
\hline & & 1 & Transporters (0) \\
\hline & & 1 & Local authority $(0)$ \\
\hline & & 28 & Subtotal (14) \\
\hline \multirow[t]{9}{*}{ Fintonia } & 1 & 3 & Nursery producers $(0)$ \\
\hline & & 6 & Producers (1) \\
\hline & & 5 & Harvesters and assemblers (3) \\
\hline & & 6 & Traders (6) \\
\hline & & 2 & Consumers (1) \\
\hline & & 2 & NGO (1) \\
\hline & & 0 & Transporters (0) \\
\hline & & 1 & Local authority (0) \\
\hline & & 25 & Subtotal (12) \\
\hline \multirow[t]{9}{*}{ Sanya } & 1 & 5 & Nursery producers (0) \\
\hline & & 7 & Producers (2) \\
\hline & & 6 & Harvesters and assemblers (5) \\
\hline & & 8 & Traders (8) \\
\hline & & 2 & Consumers (1) \\
\hline & & 2 & $\mathrm{NGO}(1)$ \\
\hline & & 2 & Transporters (2) \\
\hline & & 3 & Local authority (0) \\
\hline & & 35 & Subtotal (19) \\
\hline \multirow[t]{9}{*}{ Kabba Ferry } & 1 & 3 & Nursery producers (0) \\
\hline & & 7 & Producers (3) \\
\hline & & 5 & Harvesters and assemblers (4) \\
\hline & & 7 & Traders (7) \\
\hline & & 2 & Consumers (1) \\
\hline & & 2 & $\mathrm{NGO}(1)$ \\
\hline & & 1 & Transporters (0) \\
\hline & & 1 & Local authority (0) \\
\hline & & 28 & Subtotal (16) \\
\hline All communities & 4 & 116 & Grand total (61) \\
\hline
\end{tabular}

Number in brackets indicates the number of women within the category of participant

country. The nurseries sow the seeds in polythene bags filled with compost. Water is supplied when it is required until purchase and transplantation [18].

Nursery producers are people/structure providing mango fruits producers with planting material. Respondents affirmed that nursery producers only exist in Sanya and Fintonia. No nursery producers were specified by the respondents in the other study areas. Two types of planting material were present in the study areas: the local (non-grafted planting material) representing $80 \%$ of the available planting material and the improved planting material (grafted planting material) representing $20 \%$ of the available planting material. Local planting materials are freely available in the studied sites, on production site. Respondents in Sanya, Fintonia and Samaya affirmed to primarily obtain the improved planting material from the Sustainable and Thriving Environments for West African Regional Development (STEWARD) program and the World Agroforestry Centre (ICRAF) through the BIODEV project. More than $90 \%$ of existing improved 


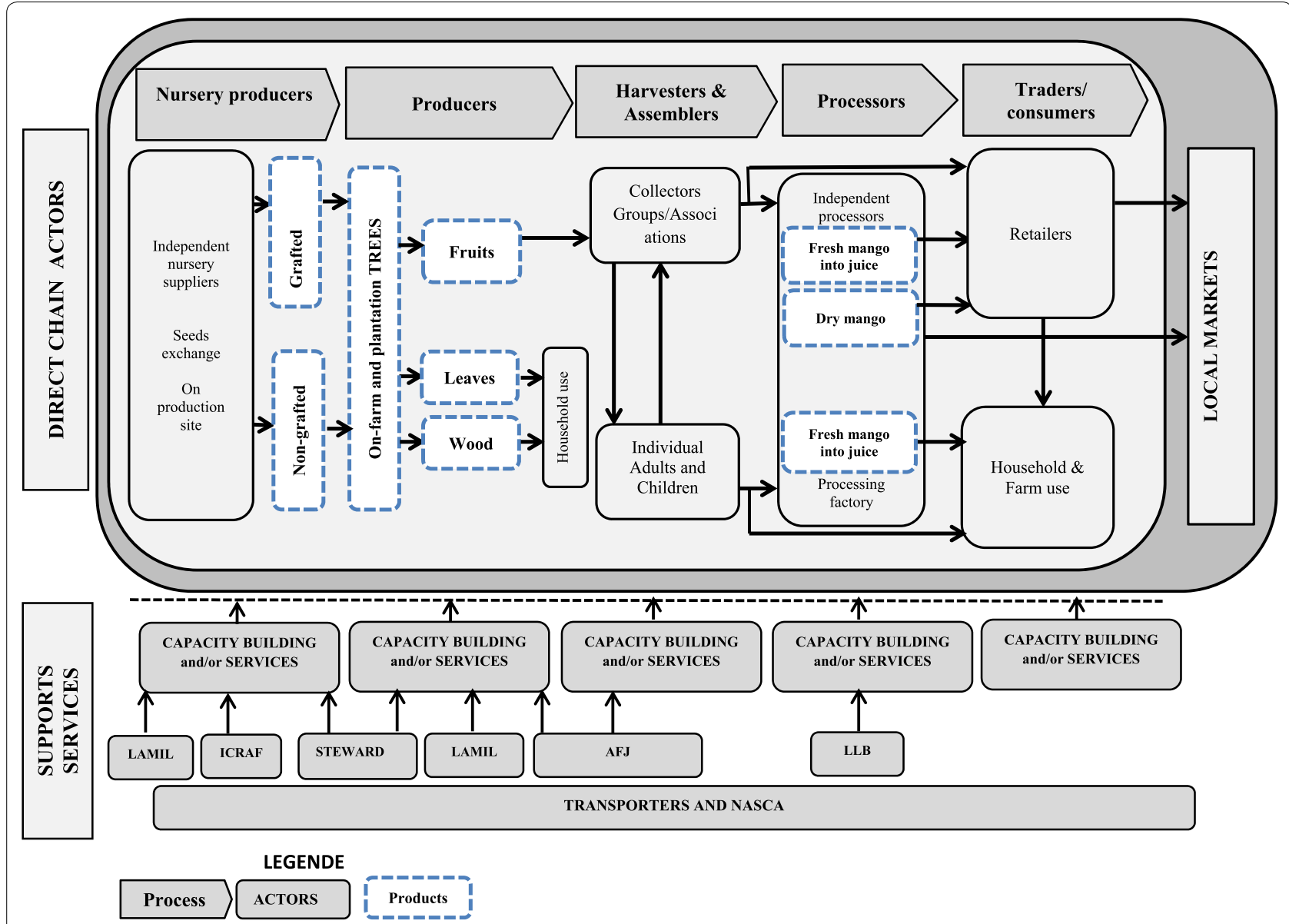

LAMIL: Trans boundary landscape management to improve livelihoods and biodiversity conservation project; ICRAF: World Agroforestry Centre; STEWARD: Sustainable and Thriving Environments for West African Regional Development AFJ: African Felix Juice; LLB: Local Loan Box; NASCA: National Commission for Social Action

Fig. 3 Mango value chain in the different sites around the Outamba Kilimi National Park (OKNP), Sierra Leone, West Africa. LAMIL Trans-boundary landscape management to improve livelihoods and biodiversity conservation project; ICRAF World Agroforestry Centre; STEWARD Sustainable and Thriving Environments for West African Regional Development; AFJ African Felix Juice; LLB Local Loan Box; NASCA National Commission for Social Action

planting materials were provided by the STEWARDS. Sanya's producers obtained additional planting material from neighbouring towns such as Guinea and Bo (about $5 \%)$. Samaya's producers sourced additional planting material estimated to $10 \%$ from markets in neighbouring towns mainly Guinea and its vicinity. This is also the case of Fintonia's producers who sourced additional planting material (estimated to 5\%) from markets in Guinea and its vicinity. Producers in Kabba Ferry affirmed to obtain about $20 \%$ of improved planting materials from neighbouring communities.

\section{Mango production}

In Sierra Leone, mango is grown by both men and women for different purposes including human food, animal food, human medicine, selling for extra income, shade, soil conservation energy source (see Additional file 1: Table 1). The percentage of men growing mango varied between 60 and $80 \%$ across the surveyed areas and that of women varied between 20 and $40 \%$ with the highest percentage of women identified in Sanya (Fig. 4a). Reasons stated by respondents on the low percentage of women as fresh mango producers were: the lack of knowledge on mango agronomic practices, mango production as a labour-intensive activity and the tradition stating that women's role is to take care of the children and the household. The mango plantations were managed in an environmentally friendly way, and nearly no inputs, fertilisers and pesticides are used. The production can be considered as organic, and as such Sierra Leonean 


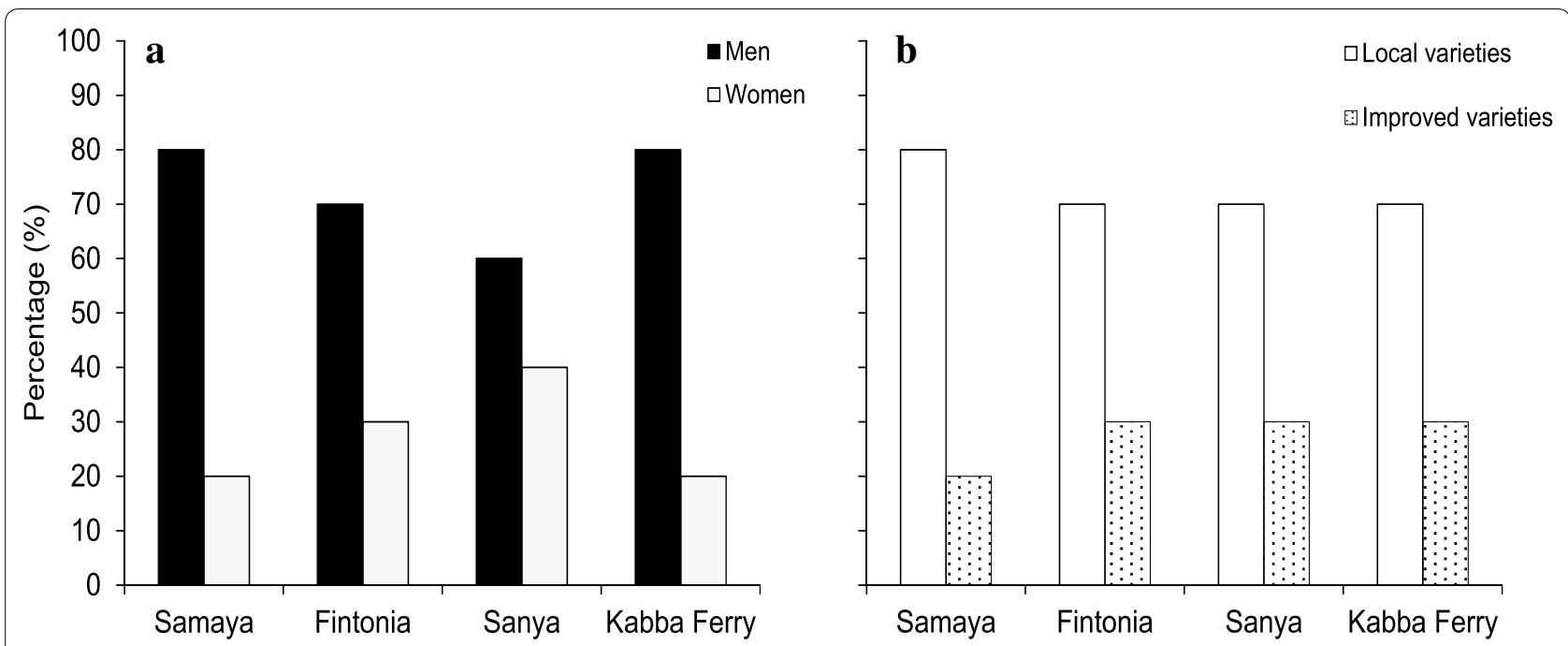

Fig. 4 Proportion of producers; men and women (a) involved in mango value chain study and local and improved mango varieties grown (b) in study sites around Outamba Kilimi National Park (OKNP)

mango may gain more value on the markets [14]. No irrigation system applied to mango trees was reported in the literature.

Several mango varieties are grown in Sierra Leone: Common mango, Laberu, Big Sheri, Shiptone, Kent, Keit, Njala 5 and Cepton [10,14]. Njala 5 and Cepton are the most preferred mango varieties by consumers and take at most 5 years to start producing [14]. The most commonly grown varieties are Common mango, Laberu, Big Sheri and Shiptone [10]. Producers grow both local and improved mango varieties for local markets as well as for household and farm use. Improved or grafted mango cultivars included among others the Kent and Keit mango, Njala 5 and Cepton. The planting material of the last two varieties is not always accessible to farmers.

Although the percentage of producers growing local varieties is far higher than that of producers growing the improved varieties (Fig. 4b), producers affirmed that their demand for improved mango planting material is high but could not be met by nursery producers. They preferred the improved varieties over the local varieties because the former start producing fruits earlier (3-5 years) than the local ones (4-10 years). Other reasons mentioned by producers are that the improved varieties have on average bigger fruits than the local varieties and customers/consumers offer better prices for bigger mangoes.

\section{Harvesting and handling}

In Sierra Leone, the harvest period generally spreads from April to September [10]. However, the production reached its peak between April and July [14, 19].
Traditionally, fruits were harvested by shaking the branches to provoke fruits drop. The dropped fruits were then collected. Such technique damaged fruits. With the out-grower scheme promoted by world Hope International, farmers were provided with skills on harvesting technique. Thus, fruits to be sold to the processing factory, Africa Felix Juice (AFJ), were harvested at specific degree of maturity, neither too green nor too ripe. The harvest was done by gently shaking branches and by using bed rice or tarpaulin in order to avoid fruits getting damaged. The fruits were then sorted and graded [14].

Around OKNP forest, both men and women generally harvest physiologically mature fruits from the tree (Fig. 5a) with no specific tool. Men harvesters often climb the mango tree, shake or pick either by hand or use short pole to pick the mature fruits. Fishing nets, empty rice bags or tarpaulin is spread below the tree to minimise physical damage on the fruit when falling.

Women harvesters often used only long pole to harvest the mature fruits. After harvesting, fruits are collected in heaps by assemblers located in the different sites and sold to the traders in bulk. Most assemblers are men as indicated in Fig. 5b, and they have their own traders to whom they supply the fruits.

\section{Processing}

In Sierra Leone, fresh mango is processed either into dried mango and/or juice (Fig. 3). Mango processing into dry mango is done mainly at household level and preferably using local varieties compared to the improved ones. The reasons why improved mango varieties are not preferred were as follows: first, they are too fleshy and 


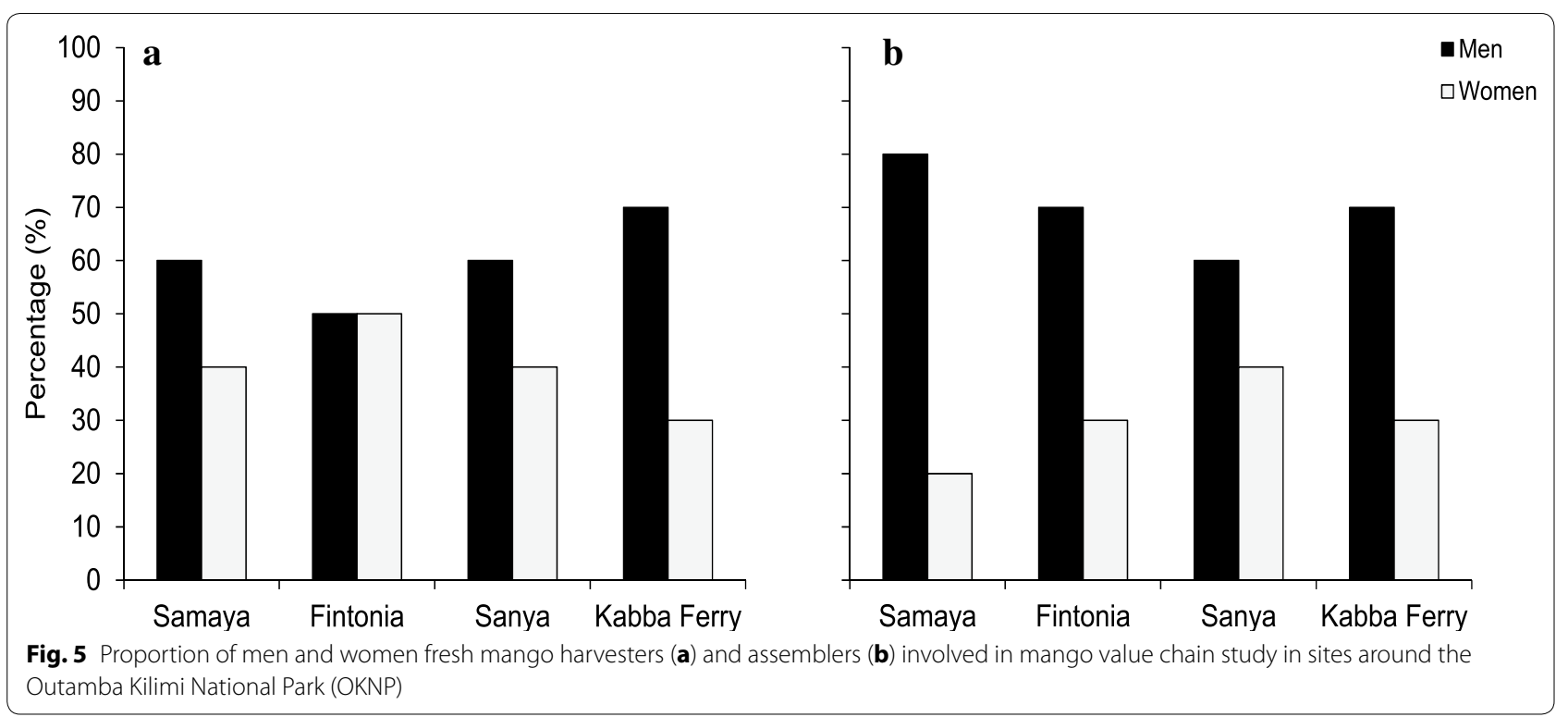

waterish, making it difficult to be processed into dried mango; second, the big size of improved mango varieties making them too bulky to transport; and third, the quantities of improved mango varieties available are small. Traditional processing methods are used and are characterised by the following steps: peeling, slicing into pieces, boiling and drying of the boiled product. Mango processing into juice and concentrate is done by AFJ. Participants in the focus group discussions were not aware of any association of mango processors in the study area.

\section{Mango trade \\ Mango for domestic and international markets}

Traditionally, Sierra Leone is not a mango exporter country and its mango value chains were one of the weakest in West Africa [10]. Most of the production was destined to home consumption, a few was sold and the remaining was lost [14]. However, recent progress towards the development of new mango value chains has been made. Two mango distribution channels can then be distinguished. The first channel consists of the local network where mango producers harvest and sell their products directly to consumers or to collectors who in their turn supply traders before reaching consumers. The setting up of AFJ factory in Newton, in the vicinity of Freetown, spawned a second channel involving processing and export. In fact, through an out-grower scheme, mango producers in areas such as Tonkolili, Bombali and Kenema were organised into cooperatives. The cooperatives sell their production to AFJ factory, Fairtrade certified. Africa Felix Juice Factory processes mango fruits into juice and concentrate, packs and exports its products to
UK, Germany, the Netherlands and the USA [14]. This latter channel offers more lucrative price for farmers since they can earn more than three times money than at the local channel. Each year within 2-3 months, AFJ factory buys mango for about 2 million pounds from farmers. Promoting mango processing and export is a great opportunity for producers to increase their income. It is worth noting that AFJ was the only mango juice and concentrate exporter from Sierra, and there was no fresh mango exporter.

\section{Mango trade around OKNP forest}

In the studied sites, both men and women were involved in mango trading, except in Sanya where all traders were women (Fig. 6a). Traders sold fresh mango as well as juice and dried mango in the local markets and within the different sites. Among the study sites, only Sanya has a periodical local market taking place once a week. The other sites sold their mango-based product either in Sanya market or in the markets taking place in neighbouring towns such as Tambe (4, 29 and $36.8 \mathrm{~km}$ from Samaya, Fintonia and Kabba Ferry, respectively), Kamakwie (20, 23 and $11.2 \mathrm{~km}$ from Samaya, Fintonia and Kabba Ferry, respectively) and Makeni (113, 111 and $99.2 \mathrm{~km}$ from Samaya, Fintonia and Kabba Ferry, respectively). Local varieties are mostly sold in these markets, except in Sanya where both local and improved varieties are equally present (Fig. 6b). The percentage of fresh mango losses varied from 40 to $70 \%$ for local varieties and $20-90 \%$ for improved varieties with the highest losses encountered in Sanya. Preferred mangoes for local markets are those that are fresh, firm and free of skin damage. 


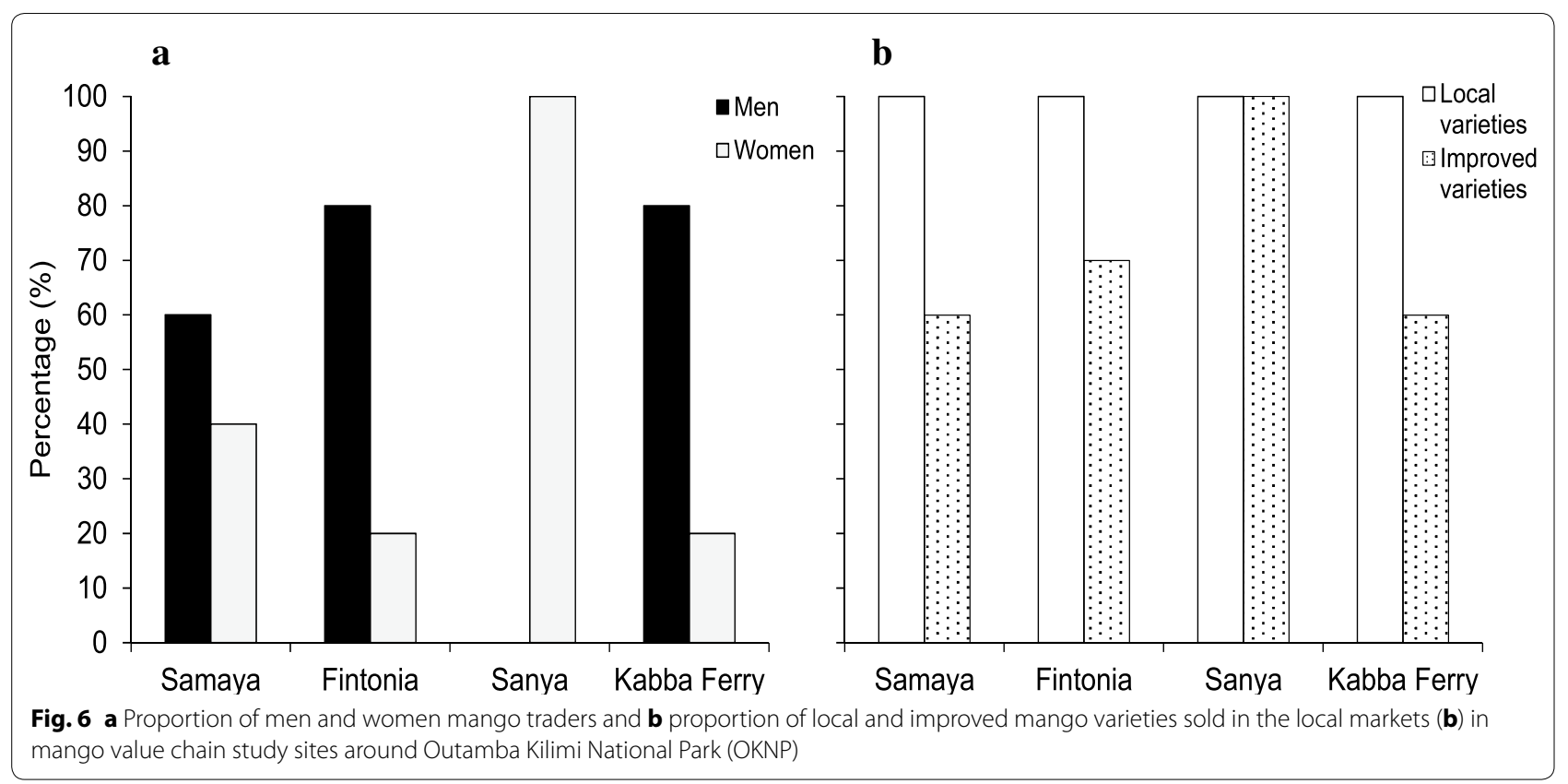

\section{Value chain support services}

Indirect actors are agencies providing support such as financial assistance or capacity building support to direct actors in the mango sector. These included ICRAF through the BIODEV project, STEWARD program, the National Commission for Social Action (NASCA), the trans-boundary Landscape Management to Improve Livelihoods and biodiversity conservation project (LAMIL), African Felix Juice (AFJ), Local Loan Box (LLB) and transporters (Fig. 3). STEWARD and LAMIL provided planting material free of charge to farmers, but these planting materials were not enough to meet the actor's demand. After these projects ended, ICRAF through BIODEV project is using different approaches by providing improved planting material to nursery producers to set up mother blocks from where scions will be harvested to graft young mango plants being raised in the nurseries and establishing community-based nursery enterprises to produce and market key tree species and varieties that are preferred and highly demanded in the different sites and beyond. STEWARD and LAMIL have also been training fresh mango producers on grafting. AFJ trains producers on agronomic practices meeting required quality of fresh mango for juice processing. AFJ also trains harvesters on best harvesting practices. The Local Loan Box (LLB) provided loan and training to mango processors with an interest rate of $50 \%$. The LLB is a community-saving method in Sanya site established by the "Local Agriculture Group". Even though the interest rate was recognised to be very high by the actors, this remains the only source of loan for farmers in crucial need of cash in scarce periods. The LLB group also buys other food products like rice and groundnut during harvesting period when prices are low and sell when price increases. NASCA helps with the maintenance of the roads to facilitate the transport of goods and agricultural products since participants affirmed that the road conditions are bad and consequently the transportation cost is high.

\section{Constraints and opportunities for mango value chain development}

The constraints encountered by actors in the chain, strategies adopted and opportunities for mango value chain improvement are presented in Additional file 2: Tables 2-6. Major constraints encountered by nursery producers in Samaya, Fintonia and Kabba Ferry were the lack of input, especially polythene bags and improved mango planting material. Water shortage during dry season and lack of appropriate tools were, respectively, reported as the major constraint for nursery production in Sanya. Lack of technical knowledge on nursery production though less important than other constraints was reported in Fintonia and Kabba Ferry. Facing these challenges, nursery producers developed adaptive strategies such as nursing of planting material done on ridges and sometimes use of drinking water packing plastics; use of local varieties; fetching water where available to water the plants; seeking advices from colleagues farmers. Availability of nursery producers in the community; high intervention by STEWARD, ICRAF and LAMIL through sensitisation were some of the opportunities to 
overcome the aforementioned challenges and promote nursery production.

In all sites, constraints faced by mango producers included the lack of mineral fertilisers, herbicides, pesticides to control the weeds and pests, and the high occurrence of wild fire. Difficulty to have access to herbicides and mineral fertilisers, water shortage during the dry season and limited access to improved agronomic practices in mango production were, respectively, ranked as main constraint for mango production in Samaya, Fintonia, Sanya, Kabba Ferry. Hand weeding, use of available organic fertiliser, fetching water from another place far from the plantation site were strategies applied by farmers to cope with the encountered constraints. Availability of organic fertilisers, availability of hired labour and support from ICRAF, STEWARD and AFJ through training on good agronomic practices were identified as opportunities for improving mango production in the target sites.

The harvesters and collectors, in all the studied sites, had limited knowledge on improved harvesting techniques and reported use of rudimentary methods to harvest mango fruits that cause injury to the mango fruit skin. In Samaya, Sanya and Kabba Ferry, the high height of local mango trees constrained fruits harvest at physiological maturity and favour loss. Intervention of ICRAF STEWARD, LAMIL and AFJ to train harvesters on improved harvest techniques and promote the cultivation of improved and dwarf varieties was viewed as potential options to overcome the challenges.

In all the surveyed sites, processors lacked appropriate knowledge and processing equipment and were left with no option other than using, local rudimentary processing materials like knives-to peel and slice the fruits, pots/ basins-to wash and fishing nets on which the sliced fruits were dried. In Kabba Ferry and Fintonia, the local rudimentary processing materials were not even always available for some processors who were compelled to borrow them from other processors. The rudimentary processing technique was perceived as labour intensive and favouring injury of operators. High proportion of infested mango by pest and disease was also identified as constraint in Kabba Ferry. The increase demand of mango-derived products on international markets may be an opportunity to be seized by processors.

Traders in Fintonia and Kabba Ferry were primarily limited in their activities by a lack of market structure in their community, while high transportation cost was the major constraint for traders in Samaya. Lack of adequate storage facilities, poor market structure, bad road network as roads are seasonal, weak (or even non-existent) communication facilities and thus making timely communication with buyers were part of the reported challenges in Fintonia, Kabba Ferry and Samaya. Facing these constraints, traders were obliged to quickly sell their products. Willingness of producers to increase mango production coupled with availability of the improved mango varieties to target sub-regional and international markets is potential to be exploited.

\section{Discussion}

The aim of this research was to analyse the mango value chains around the OKNP in Sierra Leone and find constrains and opportunities for mango value chains development. Results indicated the existence of five main actors in the chain: nursery producers, fresh mango producers, harvesters, processors and traders with strong participation of women at all levels in the value chain (Figs. 3, 4, 5, 6). Findings showed that mango value chain in the study site was poorly developed, with the fruit and fruit-based products sold in local markets (Fig. 3); fruits are also sold to the juice factory AFJ which are processed and exported to European Union. Such results are in agreement with those obtained by ECOWAS-TEN [10], who characterised the mango value chain in Sierra Leone as "weak". This is due to many constraints hampering the effectiveness of the chain.

\section{Nursery producers}

When considering the nursery producers, the fact that they lack inputs (polythene bags and improved mango seedlings for instance) to produce high-quality planting material could be viewed as a constraint to the effectiveness of the chain, since Jama et al. [20], Lillesø et al. [21], Takoutsing et al. [22] and Degrande et al. [3] stated that nursery producers should provide producers with highquality planting material to get them enthusiast to produce fruit trees allowing larger uptake of tree cultivation. The fact that input suppliers lack improved planting material could be the reason why they could not meet the high demand of fresh mango producers in improved mango varieties. The planting materials provided by STEWARD and LAMIL were very limited compared to the huge demand of actor's in the chains. It has been founded that Njala 5 and Cepton are improved and preferred mango varieties by producers, but the planting material for these varieties was not always accessible to producers. This would limit their capacity to take advantage of these relatively short-cycle varieties. Such situation should guide community nursery enterprise development towards a demand-driven seedling multiplication to respond to the demand of these planting materials. During the focus group discussion, farmers and consumers have expressed the willingness to pray a premium for the preferred varieties seedling and mango. There is a need to investigate further on the number of farmers who are willing and capable to pay for improved preferred seeds and seedlings. 


\section{Fresh mango production and harvesting}

To produce fresh mango, producers need appropriate inputs such as fertilisers, herbicides and pesticides and be trained on appropriate mango agronomic practices to ensure yielding high-quality mango fruits. According to Cetinkaya [23], training of actors in the chain is a key factor in obtaining an effective supply chain. Harvesting methods are important to ensure fruit quality $[24,25]$. In our studied sites, harvesters used poles to pick the fruit. Such harvesting method has been argued by Abu-Bakr and Hafiza [24] to induce fruit skin damage, increasing the risk of fruit decay and pest infestation.

\section{Mango processing}

The fact that local mango processors preferred fruits from the local mango cultivars over those from improved mango cultivars and that producer's demand for improved mango varieties pointed out the problem of communication gap between actors in the chain. Processors would tend to always ask for the local mango varieties, while producers would tend to shift from local to improved mango varieties production, rendering vulnerable the local mango processing activities, which are already suffering from the lack of appropriate knowledge and processing equipment. Such mismatch in preference also pointed out the need for breeders to always consider the preference of the actors in the chain and to develop cultivars or improved the existing ones to match the preference level of both the producers and processors. Also, the establishment of a platform which will comprise actor's involve in mango value chains would help to exchange on bottlenecks in the chains and improve their access to input and output markets.

\section{Traders}

Poor road network and the high transportation cost were the main constraints faced by the traders; this was also found by ECOWAS-TEN [10] and also stated by Arnold and Dewees [26] who suggested that interventions aiming at reducing constraints faced by fruit tree-based product traders are more important that incentives to plant trees on farm.

That notwithstanding, opportunities exist for the improvement of the whole mango supply chain in Sierra Leone. First, there is enough fertile land available for mango production coupled with abundant rainfall. This means that, if mango agronomic practices can be improved with strong support from service providers in the chains and the constraints at the level of suppliers tackled, there are high chances that producers will increase mango production, and consequently, there would be an increase in mango trees. In addition to their role in carbon sequestration, trees improve ground cover, organic matter in the soil, reduce the impact of falling rain [4] and enhance land value [27]. Second, there is a high demand for high-quality mango fruit/products by AFJ. If mango producers can bring themselves together as a producer's organisation, this will help them meet the demand of the AFJ company, which offers good purchasing price. Some producers can also target the international markets where demand for improved varieties is high. So, if the volume and quality of the fresh mango from Sierra Leone can be improved by multiplying trainings to actors in the chains, it would benefit all actors in the value chain. Third, the mango supply chain in Sierra Leone is getting technical/financial support from large numbers of indirect actors at different levels. If the actions of these indirect actors were more coordinated and communication between these actors improved, so that they do not repeat the same training to the same actors, but focus on filling the information gaps by providing useful trainings, the whole chain would benefit. The mismatch in cultivar preference between the processors and producers points out the need of an information sharing platform; where actors can exchange and discuss their challenges and coping strategies. The high interest rate of $50 \%$ provided by the LLB can be viewed as high, and although an opportunity, this can turn into constraint when processors will face difficulties in paying their loans back.

\section{Conclusions}

Mango is an important crop for communities living around the Outamba Kilimi National Park. Mango value chain in the studied sites is composed of five direct actors: nursery producers, fresh mango producers, harvesters and assemblers, processors and traders. The chain is poorly developed and main constraints faced by actors in the chain included the lack of inputs (polythene bags and improved mango seedlings, mineral fertilisers, herbicides, pesticide, etc.), the lack of training on appropriate mango production practices, the lack of appropriate harvesting tools, appropriate processing knowledge and equipment, the poor road network and the high transportation cost and the mismatch between actor's preference in type of mango varieties (improved and local) pointing out the need to have a platform where actor's groups can exchange and share opportunities in the input and output markets. Opportunities for the chain are that there is fertile land available, abundant rainfall, high demand for high-quality mango fruits/products at the international level, and the intervention of the indirect actors in the chains. Tackling the constraints and optimising the opportunities would help to improve the mango value chains in the studied sites and consequently will encourage producers to plant more mango trees. 


\section{Additional files}

Additional file 1: Title. List of top 10 priority tree species and functional uses in Bombali district (including Samaya, Fintonia, Kabba Ferry and Sanya Communities) in Sierra Leone. Description: The file contains the list of top 10 priority tree species and functional uses in Bombali district (including Samaya, Fintonia, Kabba Ferry and Sanya Communities) in Sierra Leone.

Additional file 2: Title. Constraints, coping strategies and opportunities for mango value chains actors in Bombali district in Sierra Leone. Description: The file contains the constraints, coping strategies and opportunities for mango nursery supply, producers, harvesters, processors and traders.

\section{Abbreviations}

AFJ: Africa Felix Juice; BIODEV: Building Biological Carbon for Rural Development and West Africa; ECOWAS: Economic Community of West African States; ICRAF: World Agroforestry Centre; LAMI: livelihoods and biodiversity conservation project; LLB: Local Loan Box; NASCA: National Commission for Social Action; OKNP: Outamba Kilimi National Park; STEWARD: Sustainable and Thriving Environments for West African Regional Development; TEN: Trade and Enterprise Experts Network.

\section{Authors' contributions}

$\mathrm{DA}, \mathrm{AD}$ and EA made substantial contributions to conception and design and acquisition of data. $D A, A D, V N F H, E A ; R B, J B, J B, A K$ were involved in analysis and interpretation of data. $D A, A D, V N F H, E A ; R B, J B, J B, A K$ were involved in drafting the manuscript or revising it critically for important intellectual content. $D A, A D, V N F H, E A ; R B, J B, J B, A K$ made final approval of the version to be published. All authors read and approved the final manuscript.

\section{Authors' information}

DA is a Marketing Scientist and SmAT-Scaling Project Manager-USAID|MALI, ICRAF West and Central Africa Region, Sahel Node.

\section{Author details}

${ }^{1}$ West and Central Africa Regional Office-Sahel Node, World Agroforestry Centre (ICRAF), PO Box E51 18, Bamako, Mali. ${ }^{2}$ West and Central Africa Regional Programme, World Agroforestry Centre (ICRAF), PO Box 16317, Yaoundé, Cameroon. ${ }^{3}$ Laboratory of Genetics, Biotechnology and Seed Sciences (Former Horticulture and Genetics Unit), Faculty of Agronomic Sciences (FSA), University of Abomey-Calavi, 01 BP 526, Cotonou, Benin.

\section{Acknowledgements}

Authors wish to thank the Building Biocarbon and Rural Development in West Africa (BIODEV) project, which is funded by the Government of Finland and implemented by a consortium composed of World Agroforestry Centre (ICRAF), Centre for International Forest Research (CIFOR), University of Helsinki, University of Eastern Finland, along with national partners identified in targeted (Sierra Leone, Burkina Faso Guinea and Mali).

\section{Availability of supporting data}

The datasets supporting the conclusions of this article are included within the article and its supplementary material.

\section{Consent to participate statement}

Prior to data collection, informed consent of participants was obtained.

\section{Consent for publication}

The respondents were informed that their opinions were to be published in a scientific paper and gave their approval.

\section{Competing interests}

The authors declare that they have no competing interests.

\section{Ethical approval}

No ethical approval was needed for this study.

\section{Funding}

Authors wish to thank the Building Biocarbon and Rural Development in West Africa (BIODEV) project, which is funded by the Government of Finland and implemented by a consortium composed of World Agroforestry Centre (ICRAF), Centre for International Forest Research (CIFOR), University of Helsinki, University of Eastern Finland, along with national partners identified in targeted (Sierra Leone, Burkina Faso Guinea and Mali).

Received: 6 July 2016 Accepted: 12 January 2017

Published online: 21 May 2017

References

1. Altieri MA, Koohafkan P. Enduring farms: climate change, smallholders and traditional farming communities. Penang: Third World Network (TWN); 2008.

2. Lin BB. Agroforestry management as an adaptive strategy against potential microclimate extremes in coffee agriculture. Agric For Meteorol. 2007;144:85-94.

3. Degrande A, Tadjo P, Takoutsing B, Asaah E, Tsobeng A, Tchoundjeu Z. Getting trees into farmers'fields: success of rural nurseries in distributing high quality planting material in Cameroon. Small Scale For. 2013;12:403-20.

4. Jagger P, Pender J. The role of trees for sustainable management of less-favored lands: the case of eucalyptus in Ethiopia. For Policy Econ. 2003;5:83-95.

5. Ræbild A, Larsen AS, Jensen JS, Ouedraogo M, De Groote S, Van Damme P, Bayala J, Diallo BO, Sanou H, Kalinganire A. Advances in domestication of indigenous fruit trees in the West African Sahel. New For. 2011:41:297-315.

6. Bokonon-Ganta AH, de Groote H, Neuenschwander P. Socio-economic impact of biological control of mango mealybug in Benin. Agric Ecosyst Environ. 2002;93:367-78.

7. Mukherjee S, Litz RE. Introduction: botany and importance. In: Litz RE, editor. The mango: botany, production and uses. Wallingford: CAB International; 2009. p. 1-18.

8. Moore L. Mango (Mangifera indica L.). Plant Guide: USDA, National Resource Conservation Services, National Plant Data Team; 2004.

9. UNCTAD (United Nations Conference on Trade and Development): 2012. http://www.unctad.info/en/Infocomm/AACP-Products/COMMODITYPROFILE-Mango/. Accessed on 2 January 2015.

10. ECOWAS-TEN. Strategic orientation document for mango value chain in the economic community of West African States (Ecowas). Geneva: International Trade Center; 2012.

11. Unruh JD. The role of land use pattern and process in the diffusion of valuable tree species. J Biogeogr. 1994;21:283-95.

12. Ottesen GG. Do upstream actors in the food chain know end-users' quality perceptions? Findings from the Norwegian salmon farming industry. Supply Chain Manag Int J. 2006;11:456-63.

13. Rey J-Y, Diallo TM, Vannière H, Didier C, Kéita S, Sangaré M. La mangue en Afrique de l'Ouest francophone. Fruits. 2004;59:121-9.

14. Hanciles O. Mangoes and pineapples - a place where Sierra Leone youth jobs are. 2013. http://www.sierraexpressmedia.com/?p=63484. Accessed on 2 Jan 2015.

15. FAO: Statistical databases. http://faostat3.fao.org/download/Q/QC/E. Rome: FAO; 2015. Accessed on October 14, 2016.

16. Ploetz R. The major diseases of mango: strategies AMD potential for sustainable management. Acta Hort. 2004:645:135-50.

17. Sheil D, Puri RK, Basuki I, Van Heist M, Wan M, Liswanti N, Rukmiyati Sardjono M, Samsoedin I, Sidiyasa K, Chrisandini Permana E. A la découverte de la biodiversité, de l'environnement et des perspectives des populations locales dans les paysages forestiers. Jakarta: Méthodes pour une étude pluridisciplinaire du paysage CIFOR; 2004.

18. Sherbro Foundation S. Eliminating poverty one tree at a time; 2013. http://sherbrofoundation.org/tag/tree-nursery/. Accessed on 25 July 2015.

19. Grudda S. Matching supply with demand in Sierra Leone's agricultural sector. 2011. https://sierramango.wordpress.com/2011/07/16/season/. Accessed on 3 Jan 2015. 
20. Jama B, Mohamed A, Mulatya J, Njui A. Comparing the "Big Five": a framework for the sustainable management of indigenous fruit trees in the drylands of East and Central Africa. Ecol Indic. 2008;8:170-9.

21. Lillesø J, Graudal L, Moestrup S, Djær E, Kindt R, Mbora A, Dawson I, Muriuki J, Roebild A, Jamnadass R. Innovation in input supply systems in smallholder agroforestry: seed sources, supply chains and support systems. Agrofor Syst. 2011;83:347-59.

22. Takoutsing B, Degrande A, Tchoundjeu Z, Asaah E, Tsobeng A. Enhancing farmers access to quality planting materials through community-based seed and seedling systems: experiences from the western highlands of cameroon. Middle East J Sci Res. 2012;12:455-63.

23. Cetinkaya B. Developing a sustainable supply chain strategy. In: Cetinkaya B, Cuthbertson R, Ewer G, Klaas-Wissing T, Piotrowicz W, Tyssen C, editors.
Sustainable supply chain management: practical ideas for moving toward best practice. Berlin: Springer; 2011. p. 17-55.

24. Abu-Bakr AG, Hafiza MI. Effect of harvesting method on quality and shelflife of mango fruits. Trop Sci. 2004;44:73-6.

25. Mazhar MS, Amin M, Malik AU, Campbell J, Johnson P. Improved harvest and desapping practices affect mango fruit quality along the supply chains. Int J Agric Biol. 2011;13:776-80.

26. Arnold J, Dewees PA. Rethinking approaches to tree management by farmers. Nat Resour Perspect. 1998;26:1-2.

27. Simmons CS, Walker RT, Wood $\mathrm{CH}$. Tree planting by small producers in the tropics: a comparative study of Brazil and Panama. Agrofor Syst. 2002;56:89-105.

\section{Submit your next manuscript to BioMed Central and we will help you at every step:}

- We accept pre-submission inquiries

- Our selector tool helps you to find the most relevant journal

- We provide round the clock customer support

- Convenient online submission

- Thorough peer review

- Inclusion in PubMed and all major indexing services

- Maximum visibility for your research

Submit your manuscript at www.biomedcentral.com/submit 